\title{
GAMBARAN PENGETAHUAN IBU TENTANG KARIES GIGI DAN TINDAKAN PENCARIAN PENGOBATAN (Kajian Pada Ibu-ibu RW 07 Kelurahan Karang Tengah, Kecamatan Karang Tengah, Banten)
}

\author{
Michael Reinhart Adiwinata*, Sri Lestari** \\ *Fakultas Kedokteran Gigi, Universitas Trisakti, Jakarta \\ **Departemen Ilmu Kesehatan Gigi Masyarakat dan Pencegahan, Fakultas Kedokteran Gigi, Universitas Trisakti, Jakarta \\ Korespondensi: Michael Reinhart, michaelrh97@gmail.com
}

\begin{abstract}
ABSTRAK
Latar belakang: karies gigi merupakan salah satu masalah gigi dan mulut yang sering dijumpai serta tidak jarang diabaikan oleh masyarakat. Penting untuk meningkatkan kesadaran dan pengetahuan masyarakat untuk menjaga ataupun mencari pengobatan gigi dan mulut sejak usia dini, khususnya melalui seorang ibu yang lebih berperan di dalam rumah tangga. Tujuan: penelitian ini adalah untuk mengetahui gambaran pengetahuan ibu tentang karies gigi dan tindakan pencarian pengobatan. Metode: penelitian ini adalah penelitian deskriptif observasional. Pengumpulan data menggunakan kuesioner melalui google form yang berisi tentang pertanyaan pengetahuan dan tindakan pencarian pengobatan. Kuesioner telah diuji validitas dan reliabilitasnya menggunakan aplikasi statistik JASP (Jeffrey's Amazing Statistic Program). Jumlah responden sebanyak 85 (delapan puluh lima) responden. Hasil: hasil penelitian didapatkan sebagian besar responden yang memiliki tingkat pengetahuan karies gigi dengan kategori baik sebanyak $71 \%$, kategori cukup 19\% dan kategori kurang $10 \%$. Untuk tindakan pencarian pengobatan dengan kategori baik sebanyak 38\%, kategori cukup 40\% dan kategori kurang 22\%. Kesimpulan: hasil penelitian menunjukkan sebagian besar responden memiliki tingkat pengetahuan tentang karies gigi dengan kategori baik dan tindakan dalam pencarian pengobatan dengan kategori cukup.
\end{abstract}

Kata kunci: ibu, karies gigi, pengetahuan, pengobatan

\section{ABSTRACT}

Background: Dental caries is one of the most common disease that usually being neglected by today's society and could affect someone's life quality. It is important to increase awareness and knowledge on maintaining dental health and treatment-seeking action regarding dental problems as early as possible, especially through mothers who have greater role in the household enviroment. Purpose: to determine the overview of dental caries knowledge and treatment-seeking action on mothers. Methods: this study is an observational descriptive study. Data was acquired through filling out questionnaires from google form. Questionnaires have been through validity and reliability test. The respondents are 85 (eighty five) mothers who reside at $R W 07$ Kelurahan Karang Tengah, Kecamatan Karang Tengah, Banten. Results: respondents mostly have high level of dental caries knowledge (71\%) and fair level of treatment seeking action with (40\%). Respondent with average level of dental caries knowledge (19\%) and average level of the treatment seeking action (40\%). Respondent with low level of dental caries knowledge (10\%) and poor level of the treatment seeking action (22\%). Conclusion: respondent at $R W 07$ Kelurahan Karang Tengah have high level of dental caries knowledge and average level of treatment seeking action.

Keywords: dental Caries, knowledge, mother, treatment

\section{PENDAHULUAN}

K

esehatan gigi dan mulut merupakan bagian dari kesehatan umum seringkali dipandang sebelah mata oleh masyarakat. ${ }^{1}$ Karies gigi merupakan salah satu masalah gigi dan mulut yang sering dijumpai serta tidak jarang diabaikan oleh masyarakat. Karies gigi adalah suatu penyakit infeksi pada jaringan keras gigi yaitu email, dentin, sementum 
yang disebabkan oleh aktivitas mikroorganisme dalam suatu karbohidrat yang diragikan. ${ }^{2}$ Salah satu penyebab terjadinya karies gigi adalah tidak terjaganya kebersihan gigi dan mulut. Hasil penelitian Alhamda (2011) didapatkan bahwa ketidakpedulian terhadap kebersihan gigi dan mulut merupakan penyebab utama timbulnya karies gigi. ${ }^{3}$

Proses penyembuhan gigi yang telah terinfeksi oleh karies, akan sulit terjadi, sehingga dibutuhkan peran dokter gigi untuk mengembalikan fungsi normal dari gigi dengan cara menumpatnya. ${ }^{4}$ Karies gigi yang diabaikan umumnya akan merusak jaringan pendukung gigi dan seringkali berujung dengan tindakan pencabutan gigi (ekstraksi gigi). ${ }^{5}$ Karies gigi dapat mempengaruhi kualitas hidup seseorang. ${ }^{6}$ Berdasarkan hasil Riset Kesehatan Dasar Indonesia tahun 2018, didapatkan prevalensi karies gigi penduduk di Indonesia sebesar 88,8\%. Pada tahap usia 25-54 tahun, prevalensi karies berkisar dari 87,0\% hingga 94,5\%. ${ }^{7}$

Data menunjukkan 75,3\% penduduk Indonesia membutuhkan perawatan gigi dan mulut serta $45,3 \%$ diantaranya merupakan penduduk yang membutuhkan perawatan gigi berlubang. Sebanyak 95,5\% penduduk dalam setahun terakhir tidak pernah melakukan pengobatan/ pemeriksaan ke tenaga medis gigi. ${ }^{7}$

Tindakan pencarian pengobatan merupakan usaha seseorang yang menderita penyakit dalam mencari kesembuhan. Tindakan ini dapat berbeda pada setiap orang, seperti antara lain: tindakan tidak mencari pengobatan, melakukan pengobatan sendiri, mencari pengobatan tradisional, melakukan pengobatan dengan minum obat-obatan dan mencari tenaga pengobatan profesional. ${ }^{8,9}$ Tindakan pencarian pengobatan gigi dan mulut di Indonesia masih menjadi salah satu masalah, karena sebanyak $42,2 \%$ penduduk Indonesia lebih memilih untuk mencari pengobatan sendiri daripada datang ke pihak profesional. ${ }^{7}$ Faktor yang memengaruhi seseorang bertindak secara umum adalah sikap dan pengetahuan. Pengetahuan merupakan dasar dari sebuah sikap dan, sebuah sikap merupakan awal dari sebuah perilaku/tindakan. ${ }^{8}$ Tindakan dari pencarian pengobatan khususnya pada bidang kedokteran gigi dipengaruhi oleh pengalaman seseorang. ${ }^{10}$

Pengetahuan, sikap dan tindakan dari orang tua, khususnya seorang ibu merupakan dasar terbentuknya perilaku anak dalam menjaga kebersihan gigi dan mulutnya. ${ }^{11}$ Orang tua yang memiliki pengetahuan, sikap dan perilaku yang tidak mendukung perilaku kebersihan gigi mulut merupakan faktor predisposisi buruknya kesehatan gigi dan mulut seorang anak. ${ }^{12,13} \mathrm{Di}$ Indonesia, proporsi tindakan pengobatan secara mandiri pada jenis kelamin perempuan adalah sebesar 40,9\%. ${ }^{7}$

Wilayah RW 07 Kelurahan Karang Tengah merupakan wilayah dengan kepadatan penduduk paling tinggi pada Kecamatan Karang Tengah dengan jumlah sebesar 37.916 penduduk. ${ }^{14}$ Berdasarkan hal diatas, penulis tertarik untuk menelaah mengenai gambaran pengetahuan ibu tentang karies dan tindakan pencarian pengobatannya.

\section{METODE PENELITIAN}

Jenis penelitian ini adalah observasional deskriptif dengan metode rancangan potong lintang (cross sectional). Pengumpulan data dilakukan pada bulan Oktober hingga bulan November 2020. Sampel penelitian ini adalah ibu-ibu yang bertempat tinggal di wilayah RW 07, Kelurahan Karang Tengah, Kecamatan Karang Tengah, Banten yang diambil dengan cara purposive sampling. Besar sampel ditentukan dengan rumus Lemeshow berjumlah 85 (delapan puluh lima) responden. Kriteria inklusi dalam penelitian ini adalah ibu yang berusia 25-54 tahun, ibu yang mengisi informed consent, ibu yang dapat mengakses google form, serta ibu yang mengisi kuesioner secara lengkap. Kriteria eksklusi penelitian ini adalah ibu yang bekerja sebagai tenaga kesehatan. Penelitian dilakukan menggunakan kuesioner berbentuk google form yang berisi tentang kuesioner pengetahuan tentang karies gigi sebanyak 9 kuesioner dan kuesioner tindakan pencarian pengobatan sebanyak 7 kuesioner. Kuesioner pengetahuan tentang karies gigi dibagi menjadi 3 kategori berdasarkan jumlah jawaban benar, $\geq 76-100 \%$ kategori baik, 60-75\% kategori cukup dan $<60 \%$ untuk kategori kurang. ${ }^{15}$ Kuesioner tindakan pencarian pengobatan memiliki 3 kategori, $\geq 76-100 \%$ kategori baik, 56-75\% kategori cukup dan $<56 \%$ untuk kategori kurang. ${ }^{16}$ Kuesioner telah diuji validitas dan reliabilitasnya menggunakan JASP (Jeffrey's Amazing Statistic Program) ${ }^{9}$ versi 1.14.1.0.

\section{HASIL PENELITIAN}

Berdasarkan hasil penelitian didapatkan hasil sebagai berikut:

Tabel 1. Distribusi Reponden Berdasarkan Karakteristik Responden

\begin{tabular}{ccc}
\hline & $\begin{array}{c}\text { Karakteristik } \\
\text { Responden }\end{array}$ & Persentase (\%) \\
Usia & $\mathbf{2 5 - 3 4}$ tahun & $19 \%$ \\
& $\mathbf{3 5 - 4 4}$ tahun & $43 \%$ \\
T5-54 tahun & $38 \%$ \\
Tingkat & SD & $1 \%$ \\
Pendidikan & SLTP & $0 \%$ \\
& SLTA & $38 \%$ \\
& S1 & $58 \%$ \\
Pekerjaan & Ibu RT & $3 \%$ \\
& Karyawan & $49 \%$ \\
& Wiraswasta & $37 \%$ \\
& Guru & $8 \%$ \\
& Psikolog & $5 \%$ \\
\hline
\end{tabular}




\begin{tabular}{|c|c|c|}
\hline \multicolumn{2}{|c|}{$\begin{array}{c}\text { Karakteristik } \\
\text { Responden }\end{array}$} & \multirow{3}{*}{$\begin{array}{c}\text { Persentase (\%) } \\
82 \% \\
18 \%\end{array}$} \\
\hline \multirow{2}{*}{ Asuransi } & Punya & \\
\hline & Tidak Punya & \\
\hline \multirow{2}{*}{$\begin{array}{c}\text { Letak } \\
\text { Layanan } \\
\text { Kesehatan }\end{array}$} & Jauh & $13 \%$ \\
\hline & Dekat & $87 \%$ \\
\hline \multirow{17}{*}{$\begin{array}{l}\text { Sumber } \\
\text { Informasi }\end{array}$} & 1 & $4 \%$ \\
\hline & 3 & $5 \%$ \\
\hline & 4 & $14 \%$ \\
\hline & 5 & $8 \%$ \\
\hline & $1 \& 2$ & $2 \%$ \\
\hline & $1 \& 3$ & $5 \%$ \\
\hline & $1 \& 4$ & $8 \%$ \\
\hline & $3 \& 4$ & $9 \%$ \\
\hline & $4 \& 5$ & $1 \%$ \\
\hline & $1,2 \& 3$ & $6 \%$ \\
\hline & $1,2 \& 4$ & $1 \%$ \\
\hline & $1,3 \& 4$ & $17 \%$ \\
\hline & $1,4 \& 5$ & $2 \%$ \\
\hline & $3,4 \& 5$ & $2 \%$ \\
\hline & $1,2,3 \& 4$ & $11 \%$ \\
\hline & $1,3,4 \& 5$ & $1 \%$ \\
\hline & $1,2,3,4 \& 5$ & $4 \%$ \\
\hline \multicolumn{3}{|c|}{ *Ibu RT: Ibu Rumah Tangga } \\
\hline \multicolumn{3}{|c|}{ *1 $\quad:$ Televisi } \\
\hline \multicolumn{3}{|c|}{ *2 $\quad:$ Radio } \\
\hline \multicolumn{2}{|c|}{ *3 : Media Cetak } & \\
\hline \multicolumn{2}{|c|}{ *4 $\quad:$ Media Sosial } & \\
\hline : Tena & sehatan & \\
\hline
\end{tabular}

Berdasarkan data hasil penelitian, pada tabel 1 dapat dilihat bahwa keseluruhan responden berusia 35-44 tahun sebanyak 43\%, usia 45-54 tahun sebanyak 38\% dan usia 25-34 tahun sebanyak 19\%. Dari tingkat pendidikan, sebagian besar berasal dari S1 sebanyak $58 \%$ dan SLTA sebanyak 38\%. Hanya sebagian kecil responden berasal dari lulusan S2 sebanyak 3\% dan lulusan SD sebanyak 1\% Berdasarkan pekerjaan sebagian besar berasal dari ibu rumah tangga sebanyak 49\% dan karyawan sebanyak 37\%. Hanya sebagian kecil responden yang bekerja sebagai wiraswasta sebanyak $8 \%$, guru $5 \%$ dan psikolog $1 \%$. Sebagian besar responden memiliki asuransi sebanyak $82 \%$ sedangkan responden yang tidak memiliki asuransi sebanyak 18\%. Responden sebagian besar memiliki lokasi tempat tinggal yang dekat dengan layanan kesehatan sebanyak 87\% dan sebanyak 13\% lainnya bertempat tinggal jauh dari lokasi layanan kesehatan. Berdasarkan sumber informasi mengenai gigi berlubang, responden sebagian besar mendapatkan informasi dari televisi, media cetak dan media sosial sebanyak $17 \%$, dari media sosial sebanyak $14 \%$ dan dari televisi, radio, media cetak dan media massa sebanyak $11 \%$.
Tabel 2. Kategori Tingkat Pengetahuan Responden Tentang Karies Gigi Berdasarkan Karakteristik Responden

\begin{tabular}{|c|c|c|c|c|}
\hline \multicolumn{2}{|c|}{ Karakteristik Responden } & \multicolumn{3}{|c|}{$\begin{array}{c}\text { Pengetahuan Tentang } \\
\text { Karies Gigi }\end{array}$} \\
\hline & & Baik & Cukup & Kurang \\
\hline \multirow{3}{*}{ Usia } & 25-34 tahun & $13 \%$ & $5 \%$ & $1 \%$ \\
\hline & 35-44 tahun & $31 \%$ & $8 \%$ & $5 \%$ \\
\hline & 45-54 tahun & $27 \%$ & $6 \%$ & $5 \%$ \\
\hline \multirow{5}{*}{$\begin{array}{c}\text { Tingkat } \\
\text { Pendidikan }\end{array}$} & SD & $0 \%$ & $1 \%$ & $0 \%$ \\
\hline & SLTP & $0 \%$ & $0 \%$ & $0 \%$ \\
\hline & SLTA & $21 \%$ & $7 \%$ & $10 \%$ \\
\hline & S1 & $47 \%$ & $10 \%$ & $1 \%$ \\
\hline & $\mathbf{S 2}$ & $2 \%$ & $1 \%$ & $0 \%$ \\
\hline \multirow{5}{*}{ Pekerjaan } & Ibu RT & $31 \%$ & $11 \%$ & $8 \%$ \\
\hline & Karyawan & $28 \%$ & $7 \%$ & $1 \%$ \\
\hline & Wiraswasta & $7 \%$ & $0 \%$ & $1 \%$ \\
\hline & Guru & $5 \%$ & $0 \%$ & $0 \%$ \\
\hline & Psikolog & $0 \%$ & $1 \%$ & $0 \%$ \\
\hline \multirow{2}{*}{ Asuransi } & Punya & $58 \%$ & $20 \%$ & $5 \%$ \\
\hline & $\begin{array}{l}\text { TIdak } \\
\text { Punya }\end{array}$ & $13 \%$ & $3 \%$ & $1 \%$ \\
\hline \multirow{17}{*}{$\begin{array}{l}\text { Sumber } \\
\text { Informasi }\end{array}$} & 1 & $2 \%$ & $1 \%$ & $0 \%$ \\
\hline & 3 & $2 \%$ & $2 \%$ & $0 \%$ \\
\hline & 4 & $11 \%$ & $4 \%$ & $0 \%$ \\
\hline & 5 & $5 \%$ & $2 \%$ & $1 \%$ \\
\hline & $1 \& 2$ & $0 \%$ & $2 \%$ & $0 \%$ \\
\hline & $1 \& 3$ & $5 \%$ & $0 \%$ & $0 \%$ \\
\hline & $1 \& 4$ & $5 \%$ & $2 \%$ & $1 \%$ \\
\hline & $3 \& 4$ & $7 \%$ & $2 \%$ & $0 \%$ \\
\hline & $4 \& 5$ & $1 \%$ & $0 \%$ & $0 \%$ \\
\hline & $1,2 \& 3$ & $4 \%$ & $1 \%$ & $1 \%$ \\
\hline & $1,2 \& 4$ & $1 \%$ & $0 \%$ & $0 \%$ \\
\hline & $1,3 \& 4$ & $13 \%$ & $4 \%$ & $0 \%$ \\
\hline & $1,4 \& 5$ & $1 \%$ & $1 \%$ & $0 \%$ \\
\hline & $3,4 \& 5$ & $2 \%$ & $0 \%$ & $0 \%$ \\
\hline & $1,2,3 \& 4$ & $7 \%$ & $1 \%$ & $2 \%$ \\
\hline & $1,3,4 \& 5$ & $1 \%$ & $0 \%$ & $0 \%$ \\
\hline & $1,2,3,4 \& 5$ & $4 \%$ & $0 \%$ & $0 \%$ \\
\hline
\end{tabular}

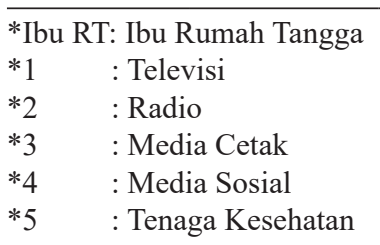

Berdasarkan kategori pengetahuan tentang karies gigi, tabel 2 menunjukkan sebagian besar responden memiliki pengetahuan tentang karies gigi dengan kategori baik pada usia 35-44 tahun sebanyak 31\%, 45-54 tahun sebanyak 27\%, 25-34 tahun sebanyak 13\%. Berdasarkan tingkat pendidikan, tingkat pengetahuan kategori baik didapatkan pada responden dengan tingkat pendidikan S1 sebanyak $47 \%$, SLTA sebanyak $21 \%$ dan S2 sebanyak 2\%. Berdasarkan pekerjaan, tingkat pengetahuan kategori 
baik didapatkan pada responden dengan pekerjaan ibu rumah tangga sebanyak $31 \%$, pekerjaan sebagai karyawan sebanyak $28 \%$, wiraswasta sebanyak $7 \%$, dan guru sebanyak 5\%. Berdasarkan asuransi, tingkat pengetahuan kategori baik didapatkan pada responden yang memiliki asuransi sebanyak 58\%, pada kategori cukup sebanyak $20 \%$ dan pada responden yang tidak memiliki asuransi serta memiliki tingkat pengetahuan kategori baik sebanyak $13 \%$.

Tabel 3. Kategori Tindakan Pencarian Pengobatan Berdasarkan Karakteristik Responden

\begin{tabular}{|c|c|c|c|c|}
\hline \multicolumn{2}{|c|}{ Karakteristik Responden } & \multicolumn{3}{|c|}{$\begin{array}{c}\text { Tindakan Pencarian } \\
\text { Pengobatan }\end{array}$} \\
\hline & & Baik & Cukup & Kurang \\
\hline \multirow{3}{*}{ Usia } & 25-34 tahun & $10 \%$ & $7 \%$ & $2 \%$ \\
\hline & 35-44 tahun & $16 \%$ & $18 \%$ & $9 \%$ \\
\hline & 45-54 tahun & $12 \%$ & $15 \%$ & $11 \%$ \\
\hline \multirow{5}{*}{$\begin{array}{l}\text { Tingkat } \\
\text { Pen- } \\
\text { didikan }\end{array}$} & SD & $0 \%$ & $0 \%$ & $1 \%$ \\
\hline & SLTP & $0 \%$ & $0 \%$ & $0 \%$ \\
\hline & SLTA & $11 \%$ & $14 \%$ & $13 \%$ \\
\hline & S1 & $25 \%$ & $26 \%$ & $7 \%$ \\
\hline & $\mathbf{S 2}$ & $2 \%$ & $0 \%$ & $1 \%$ \\
\hline \multirow{5}{*}{ Pekerjaan } & Ibu RT & $20 \%$ & $15 \%$ & $14 \%$ \\
\hline & Karyawan & $13 \%$ & $19 \%$ & $5 \%$ \\
\hline & Wiraswasta & $2 \%$ & $5 \%$ & $1 \%$ \\
\hline & Guru & $1 \%$ & $1 \%$ & $2 \%$ \\
\hline & Psikolog & $1 \%$ & $0 \%$ & $0 \%$ \\
\hline \multirow{2}{*}{ Asuransi } & Punya & $34 \%$ & $32 \%$ & $16 \%$ \\
\hline & Tidak Punya & $4 \%$ & $8 \%$ & $6 \%$ \\
\hline \multirow{2}{*}{$\begin{array}{c}\text { Letak } \\
\text { Layanan } \\
\text { Kesehatan }\end{array}$} & Jauh & $6 \%$ & $5 \%$ & $2 \%$ \\
\hline & Dekat & $32 \%$ & $35 \%$ & $20 \%$ \\
\hline \multirow{17}{*}{$\begin{array}{c}\text { Sumber } \\
\text { Informasi }\end{array}$} & 1 & $2 \%$ & $1 \%$ & $0 \%$ \\
\hline & 3 & $2 \%$ & $2 \%$ & $0 \%$ \\
\hline & 4 & $9 \%$ & $5 \%$ & $0 \%$ \\
\hline & 5 & $4 \%$ & $2 \%$ & $2 \%$ \\
\hline & $1 \& 2$ & $1 \%$ & $1 \%$ & $0 \%$ \\
\hline & $1 \& 3$ & $2 \%$ & $1 \%$ & $1 \%$ \\
\hline & $1 \& 4$ & $4 \%$ & $4 \%$ & $1 \%$ \\
\hline & $3 \& 4$ & $7 \%$ & $2 \%$ & $0 \%$ \\
\hline & $4 \& 5$ & $1 \%$ & $0 \%$ & $0 \%$ \\
\hline & $1,2 \& 3$ & $1 \%$ & $5 \%$ & $0 \%$ \\
\hline & $1,2 \& 4$ & $0 \%$ & $1 \%$ & $0 \%$ \\
\hline & $1,3 \& 4$ & $13 \%$ & $4 \%$ & $0 \%$ \\
\hline & $1,4 \& 5$ & $2 \%$ & $0 \%$ & $0 \%$ \\
\hline & $3,4 \& 5$ & $2 \%$ & $0 \%$ & $0 \%$ \\
\hline & $1,2,3 \& 4$ & $6 \%$ & $5 \%$ & $0 \%$ \\
\hline & $1,3,4 \& 5$ & $1 \%$ & $0 \%$ & $0 \%$ \\
\hline & $1,2,3,4 \& 5$ & $4 \%$ & $0 \%$ & $0 \%$ \\
\hline
\end{tabular}

\footnotetext{
*Ibu RT: Ibu Rumah Tangga

*1 : Televisi

*2 : Radio

*3 : Media Cetak

*4 : Media Sosial

*5 : Tenaga Kesehatan
}

Berdasarkan kategori tindakan pencarian pengobatan, tabel 3 menunjukkan responden memiliki tindakan pencarian pengobatan dengan kategori baik pada usia 35-44 tahun sebanyak 16\%, 45-54 tahun sebanyak $12 \%$, dan 25-34 tahun sebanyak $10 \%$. Berdasarkan tingkat pendidikan, tindakan pencarian pengobatan dengan kategori baik didapatkan pada responden dengan tingkat pendidikan S1 sebanyak $25 \%$, SLTA sebanyak $11 \%$ dan S2 sebanyak $2 \%$. Berdasarkan pekerjaan, tindakan pencarian pengobatan dengan kategori baik didapatkan pada responden dengan pekerjaan ibu rumah tangga sebanyak 20\% dan karyawan sebanyak 13\%. Berdasarkan asuransi, tindakan pencarian pengobatan dengan kategori baik didapatkan pada responden yang memiliki asuransi sebanyak $34 \%$ dan sebanyak $4 \%$ pada responden yang tidak memiliki asuransi. Berdasarkan letak layanan kesehatan, tindakan pencarian pengobatan kategori baik didapatkan pada sebagian besar responden yang memiliki tempat tinggal dekat dengan layanan kesehatan sebanyak $32 \%$ dan sebanyak $6 \%$ pada responden yang memiliki tempat tinggal jauh dengan layanan kesehatan.

Tabel 4. Distribusi Responden Berdasarkan Tingkat Pengetahuan Karies Gigi

\begin{tabular}{ccc}
\hline $\begin{array}{c}\text { Tingkat } \\
\text { Pengetahuan } \\
\text { Tentang Karies } \\
\text { Gigi }\end{array}$ & Frekuensi & $\begin{array}{c}\text { Persentase } \\
(\%)\end{array}$ \\
\hline Baik & & \\
Cukup & 60 & $71 \%$ \\
Kurang & 16 & $19 \%$ \\
Total & 9 & $10 \%$ \\
\hline
\end{tabular}

Tabel 4 menunjukkan sebagian besar responden memiliki pengetahuan tentang karies gigi dengan kategori baik sebanyak 71\%, kategori cukup sebanyak 19\% dan kategori kurang sebanyak 10\%. Penjelasan secara rinci dapat dilihat pada tabel 4 berikut:

Tabel 5. Distribusi Responden Berdasarkan Kategori Tindakan Pencarian Pengobatan

\begin{tabular}{ccc}
\hline $\begin{array}{c}\text { Tindakan } \\
\text { Pencarian } \\
\text { Pengobatan }\end{array}$ & Frekuensi & $\begin{array}{c}\text { Persentase } \\
(\%)\end{array}$ \\
\hline Baik & 32 & $38 \%$ \\
Cukup & 34 & $40 \%$ \\
Kurang & 19 & $22 \%$ \\
\hline Total & 85 & $100 \%$ \\
\hline
\end{tabular}

Tabel 5 menunjukkan sebagian besar responden memiliki kategori baik pada tindakan pencarian 
pengobatan sebanyak 38\%, kategori cukup sebanyak $40 \%$ dan kategori kurang sebanyak $22 \%$.

\section{PEMBAHASAN}

Data penelitian berdasarkan kategori usia menunjukkan responden terdiri dari kelompok usia 2534 tahun sebanyak 19\%, usia 35-44 tahun sebanyak 43\% dan 45-54 tahun sebanyak 38\%. Menurut Badan Pusat Statistik Kota Tangerang (2020), jumlah ini kurang sesuai dengan data yang menyatakan bahwa persebaran penduduk jenis kelamin wanita pada Kelurahan Karang Tengah paling banyak terdapat pada usia 25-34 tahun. ${ }^{14}$ Hal ini dapat disebabkan karena wanita pada kategori usia 25-34 tahun biasanya belum menikah dan belum memiliki anak sehingga tidak termasuk pada sampel penelitian kali ini.

Dilihat dari tingkat pendidikan, Sebagian besar responden memiliki pendidikan strata 1 atau sarjana (S1) sebanyak 58\% dan lulusan SLTA sebanyak sebanyak 38\%. Terlihat bahwa responden dengan pendidikan strata 2 atau magister (S2) sebanyak 3\% dan lulusan SD sebanyak 1\%. Menurut Badan Pusat Statistik Kota Tangerang (2020), banyaknya responden dengan tingkat pendidikan menengah keatas ini dapat dikarenakan sarana dan prasarana pendidikan yang memadai serta kondisi sosial ekonomi masyarakat di Kota Tangerang tergolong cukup baik. ${ }^{14}$

Berdasarkan pekerjaan, sebagian besar responden merupakan ibu rumah tangga sebanyak 49\%, karyawan sebanyak $37 \%$, wiraswasta 8 , guru sebanyak $5 \%$ dan psikolog sebanyak 1\%. Menurut Badan Pusat Statistik Kota Tangerang (2020), responden sebagian besar berasal dari ibu rumah tangga dikarenakan RW 07 Kelurahan Karang Tengah merupakan daerah perumahan yang padat penduduk. ${ }^{14}$

Berdasarkan hasil penelitian, didapatkan sebanyak $82 \%$ menjawab memiliki asuransi dan sebanyak $18 \%$ responden menjawab tidak memiliki asuransi. Menurut BPJS Kesehatan (2020), data sudah sesuai dengan data yang menyatakan bahwa terhitung tanggal 31 Desember 2020, peserta program sudah mencapai $83 \%$ dari total penduduk Indonesia. ${ }^{17}$

Dari aspek letak layanan kesehatan, sebanyak $87 \%$ menjawab lokasi pelayanan kesehatan berada dekat dengan tempat tinggal responden dan sebanyak $13 \%$ responden lainnya menjawab lokasi pelayanan kesehatan berada jauh dari tempat tinggalnya. Data tersebut menunjukkan letak layanan kesehatan berpengaruh dengan tindakan pencarian pengobatan seseorang. Menurut Notoatmodjo (2012), semakin mudahnya prosedur untuk mendapatkan perawatan, maka akan semakin besar pula keinginan seseorang akan melakukan pengobatan. ${ }^{8}$

Seluruh responden mengaku sudah pernah mendapatkan informasi mengenai gigi berlubang, sebagian besar menjawab berasal dari televisi, media cetak dan media sosial yaitu sebanyak 14 responden (17\%), dari media sosial sebanyak 12 responden (14\%). Dari data terlihat bahwa responden tidak memiliki kesulitan untuk memperoleh informasi. Menurut Notoatmodjo (2012), banyaknya sumber dari media sosial disebabkan karena sampel penelitian berada pada usia dewasa, dimana pada masa ini responden dapat dengan mudah mengakses informasi dan menemukan pengetahuan baru salah satunya mengenai gigi berlubang. ${ }^{8}$

Berdasarkan hasil penelitian didapatkan responden yang berusia 35-44 tahun memiliki tingkat pengetahuan baik yaitu sebanyak $31 \%$, usia 45-54 tahun sebanyak 27\% dan usia 25-34 tahun sebanyak $13 \%$. Data tersebut menunjukkan semakin dewasa usia seseorang, semakin tinggi tingkat pengetahuannya. Hasil penelitian Purnomo dan Kurniawati (2017), menyatakan bahwa seseorang yang bertambah dewasa memiliki daya tangkap dan pola pikir yang lebih baik, sehingga penarikan informasi akan semakin mudah dan lebih banyak. ${ }^{18}$

Hasil penelitian didapatkan responden yang berusia 35-44 tahun memiliki tindakan pencarian pengobatan kategori baik yaitu sebanyak $16 \%$, usia 45 54 tahun sebanyak 12\%, pada kategori cukup, usia 3544 tahun sebanyak 18\% dan usia 45-54 tahun sebanyak $15 \%$. Data tersebut menunjukkan usia seseorang tidak memengaruhi tindakan pencarian pengobatan. Hasil penelitian Nelwan (2011), menyatakan bahwa semakin dewasa usia seseorang, maka pengalaman akan bertambah, dan kemungkinan seseorang menderita sakit gigi akan lebih besar, sehingga kebutuhan seseorang untuk berobat akan lebih tinggi. Seseorang yang belum pernah merasakan sakit cenderung tidak akan melakukan tindakan pencarian pengobatan hingga rasa sakit mulai timbul. ${ }^{10}$ Menurut Notoatmodjo (2012), faktor utama dari seseorang untuk mencari pengobatan adalah mudah tidaknya akses seseorang tersebut untuk berobat, jaminan kesembuhan setelah berobat dan kebutuhan seseorang untuk mengobati penyakitnya. ${ }^{8}$ Faktor usia hanya merupakan salah satu faktor predisposisi yang memengaruhi tindakan pencarian pengobatan seseorang.

Responden yang berpendidikan S1 memiliki pengetahuan tentang karies gigi dengan kategori baik sebanyak 47\%, dan SLTA sebanyak 21\%. Responden dengan tingkat pendidikan S1 memiliki tindakan pencarian pengobatan dengan kategori baik sebanyak $25 \%$, SLTA sebanyak $11 \%$ dan pada kategori cukup, tingkat pendidikan S1 sebanyak 26\% serta SLTA sebanyak 14\%. Hasil tersebut menunjukkan tingkat pendidikan responden merupakan salah satu faktor yang memengaruhi tingkat pengetahuan karies gigi dan tindakan pencarian pengobatan. Hasil penelitian Purwati (2013), menyatakan bahwa semakin tinggi tingkat pendidikan seseorang maka akan semakin mudah seseorang menerima informasi dan penge- 
tahuan, sehingga perilaku atau tindakannya juga akan lebih baik. ${ }^{19}$

Hasil penelitian didapatkan responden yang bekerja sebagai ibu rumah tangga memiliki tingkat pengetahuan dengan kategori baik sebanyak 31\%, sebagai karyawan $28 \%$ dan sebagai wiraswasta sebanyak 7\%. Hasil tersebut menunjukkan bahwa responden memiliki pengetahuan dengan kategori baik. Seseorang akan mendapatkan informasi dari lingkungan kerjanya. Menurut Mubarak (2007), Pekerjaan memengaruhi penghasilan seseorang yang berpengaruh terhadap kemudahan mendapatkan informasi. ${ }^{20}$ Menurut Budiharto (2010) pekerjaan secara tidak langsung memengaruhi tingkat ekonomi seseorang karena dengan tingkat ekonomi yang mencukupi, seseorang tidak akan merasakan kesulitan memiliki fasilitas untuk memperoleh informasi. ${ }^{21}$

Sebagian besar responden yang bekerja sebagai ibu rumah tangga, karyawan dan wiraswasta memiliki tindakan pencarian pengobatan dengan kategori baik masing-masing yaitu 20\%, 13\% dan 2\%. Pekerjaan merupakan faktor utama yang memengaruhi tingkat ekonomi. Tingkat ekonomi yang mencukupi akan memudahkan seseorang untuk mendapatkan informasi. Tingkat ekonomi juga memengaruhi cara pandang dan persepsi seseorang mengenai pengobatan. Hasil penelitian Irmawati dan Kurniasari (2012) dan Syaer (2010), menyatakan bahwa seseorang yang memiliki jenis pekerjaan yang lebih baik atau tingkat penghasilan yang lebih tinggi, cenderung akan mencari pengobatan kepada tenaga kesehatan yang lebih profesional. ${ }^{22,23}$ Pada umumnya peran tulang punggung keluarga diperankan oleh suami, sehingga sulit untuk mengukur tingkat ekonomi dari pekerjaan seorang ibu.

Responden yang memiliki asuransi memiliki tingkat pengetahuan dengan kategori baik sebanyak $58 \%$ dan responden tanpa asuransi sebanyak $13 \%$. Data menunjukkan bahwa responden dengan tingkat pengetahuan baik memiliki asuransi yang dapat membantu seseorang untuk mendapatkan layanan kesehatan. Menurut penelitian Manu (2019), salah satu faktor yang memengaruhi perilaku pencarian pengobatan adalah konsep sehat dari seseorang, sehingga seseorang yang memiliki asuransi secara tidak langsung memiliki persepsi kesehatan yang lebih baik. $^{24}$

Responden yang mempunyai asuransi didapatkan tindakan pencarian pengobatan dengan kategori baik sebanyak $34 \%$ dan responden yang tidak memiliki asuransi sebanyak 4\%. Data tersebut menunjukkan bahwa asuransi berpengaruh kepada tindakan pencarian pengobatan responden. Hasil penelitian Irmawati dan Kurniasari (2012) dan Syaer (2010), menyatakan bahwa seseorang yang memiliki tingkat ekonomi yang lebih tinggi, cenderung akan mencari pengobatan kepada tenaga kesehatan yang lebih profesional. ${ }^{22,23}$ Adanya asuransi, tindakan pen- carian pengobatan responden akan tidak terbatasi oleh faktor biaya, sehingga responden dapat datang berobat kepada tenaga kesehatan yang tepat.

Berdasarkan dekat-tidaknya tempat tinggal dengan lokasi layanan kesehatan, didapatkan tindakan pencarian pengobatan responden yang bertempat tinggal dekat dengan kategori baik sebanyak 32\% dan bertempat tinggal jauh sebanyak $6 \%$. Data menunjukkan bahwa letak layanan kesehatan merupakan faktor yang memengaruhi tindakan pencarian pengobatan. Hasil penelitian Manu (2019), menyatakan bahwa salah satu faktor yang memengaruhi tindakan pencarian pengobatan adalah adanya fasilitas untuk berobat. ${ }^{24}$

Berdasarkan sumber informasi gigi berlubang, sebagian besar responden yang mendapat informasi gigi berlubang dari televisi, media cetak, dan media sosial memiliki pengetahuan dengan kategori tinggi. Hal ini menunjukkan bahwa pengaruh dari media massa memiliki dampak terhadap pengetahuan responden. Hasil penelitian Irmawati dan Kurniasari (2012), menyatakan bahwa individu dengan sumber informasi lebih banyak akan memiliki pengetahuan yang lebih luas. ${ }^{23}$ Berdasarkan tindakan pencarian pengobatan, sebagian besar responden yang mendapatkan sumber informasi gigi berlubang dari media sosial dan tenaga kesehatan memiliki tindakan pencarian pengobatan dengan kategori baik. Data menunjukkan peran dari media sosial dan tenaga kesehatan khususnya dokter gigi memiliki peran dalam terbentuknya tindakan pencarian pengobatan karies gigi.

Hasil keseluruhan penelitian menunjukkan sebagian besar responden memiliki tingkat pengetahuan karies gigi termasuk kategori baik sebanyak 71\% serta kategori tindakan pencarian pengobatannya termasuk kategori baik sebanyak 38\% dan kategori cukup sebanyak 40\%. Hasil penelitian tidak sesuai dengan data Riset Kesehatan Dasar Indonesia Tahun 2018 yang menyatakan bahwa tindakan pencarian pengobatan pada Provinsi Banten hanya sebesar 4,4\%. ${ }^{7}$ Hal ini dapat disebabkan karena penelitian dilakukan hanya pada RW 07 Kelurahan Karang Tengah yang merupakan wilayah sebagian kecil dari total wilayah provinsi Banten. ${ }^{14}$

\section{KESIMPULAN DAN SARAN}

Berdasarkan penelitian yang telah dilakukan, dapat disimpulkan bahwa sebagian besar responden memiliki tingkat pengetahuan karies gigi dengan kategori baik sebanyak $71 \%$ serta tindakan pencarian pengobatan dengan kategori baik sebanyak 38\% dan kategori cukup sebanyak 40\%. Hal ini disebabkan karena sebagian besar responden memiliki pendidikan menengah keatas, fasilitas untuk memperoleh informasi yang memadai, adanya asuransi serta letak layanan kesehatan yang dekat dengan tempat tinggal responden. Kesadaran dan pengetahuan untuk menjaga gigi dan mulut harus ditanamkan sejak 
usia dini, khususnya melalui seorang ibu yang lebih berperan di dalam rumah tangga. Untuk penelitian selanjutnya, dapat dilakukan kajian dari faktorfaktor lain yang memengaruhi pengetahuan tentang karies gigi dan tindakan pencarian pengobatan. Perlu dilakukan penelitian dengan sampel lebih banyak untuk penelitian yang lebih akurat.

\section{DAFTAR PUSTAKA}

1. Sukma C. Hubungan Pola Menyikat Gigi Dengan Indeks DMF-T Pada Siswa Kelas VI di MINU Nadla'ul Ulum Kecamatan Blimbing Malang. Universitas Brawijaya; 2013. P. 2.

2. Sukmana BI. Gambaran Karies dengan Menggunakan DMF-T pada Masyarakat Pesisir Pantai Kelurahan Takisung Kecamatan Takisung Kabupaten Tanah Laut. Dentino. 2016;1(2): 75-78.

3. Alhamda S. Status Kebersihan Gigi dan Mulut dengan Status Karies Gigi (Kajian pada Murid Kelompok Umur 12 Tahun di Sekolah Dasar Negeri Kota Bukittinggi). Berita Kedokteran Masyarakat. 2011;27(2): 108-115.

4. Rathee M, Sapra A. Dental Caries. StatPearls [I n t e r n e t]. StatPearls Publishing; 2019. [c i t e d 2020 Sep 20] Available from: https:/www.ncbi.nlm.nih.gov/books/ NBK551699

5. Tronstad L. Clinical endodontics: a textbook. $3^{\text {rd }}$ ed. Stuttgart; New York: Thieme; 2009. Chapter The Endodontium; P. 15-16.

6. Martins MT, Sardenberg F, Bendo CB, Vale MP, Paiva SM, Pordeus IA. Dental Caries Are More Likely to Impact On Children's Quality of Life than Malocclusion or Traumatic Dental Injuries. Europe J Paediatric Dental. 2018;19(3): P. 194-198.

7. Ministry of Health Republik Indonesia. Laporan Nasional Riset Kesehatan Dasar 2018. 2018. P 181-220.

8. Notoatmodjo S. Promosi Kesehatan Dan Perilaku Kesehatan. Jakarta: Rineka Cipta; 2012. P. 151,223.

9. Widayati A. Health seeking behavior di Kalangan Masyarakat Urban di Kota Yogyakarta. J Farm Sains dan Komunitas (Journal Pharm Sci Community). 2016;9(2).

10. Nelwan JJ. Faktor-faktor yang Mempengaruhi Tingginya Kasus Karies Gigi pada Anak Panti Asuhan Yataama Al-Firdausi di Wilayah Kerja Puskesmas Ngesrep Tahun 2011. J Kesehatan Gigi (Dental Health Journal). 2015;3(2): P. 106-112.

11. Aprilia K, Sulastri S, Widayati A. Gambaran Tingkat Pengetahuan Ibu tentang Karies Gigi dengan Jumlah Karies pada Anak TK Masyithoh Maesan Lendah Kulon Progo. Poltekkes Kemenkes Yogyakarta; 2019. P. 30-35.
12. Natamiharja L. Peran Orangtua Terhadap Pemeliharaan Kesehatan Gigi dan Mulut Anak dan Status Kesehatan Gigi dan Mulut Anak Kelas II SD Medan: Parent's Role of Dental Oral Health Care and Dental Health Status of The Second Grade Student In Medan. Dentika Dent J. 2011;16(2): P. 163.

13. Riyanti E. Pengenalan dan perawatan kesehatan gigi anak sejak dini. Universitas Pajajaran. [I n t e r n e t]. 2015 [c i t e d 2020 Jun 6]; Available from: http://resources.unpad.ac.id/ unpad-content/uploads/publikasidosen.pdf

14. BPS Kota Tangerang. Kecamatan Karang Tengah Dalam Angka 2020. 2020 ${ }^{\text {th }}$ ed. Tangerang: BPS Kota Tangerang; 2020. P. 55-99.

15. Arikunto S. Prosedur Penelitian Suatu Pendekatan Praktik. Jakarta: Rineka cipta; 2010. P. 268

16. Budiman \& Riyanto. Kapita Selekta Kuesioner: Pengetahuan dan Sikap dalam Penelitian Kesehatan. Jakarta: Salemba Medika; 2013.

17. BPJS Kesehatan. BPJS Kesehatan [I $n$ t e r $n$ e t]. BPJS Kesehatan. 2020 [c i t e d 2020 Jan 20]. Available from: www.bpjs-kesehatan.go.id/bpjs/

18. Purnomo L, Kurniawati D. Hubungan Tingkat Pendidikan Kepala Keluarga dengan Perilaku Pencarian Pengobatan Gigi di RW 02, Kelurahan Kowangan, Kecamatan Temanggung. Universitas Muhammadiyah Surakarta; 2017.

19. Purwati W. Tingkat Pengetahuan tentang Kesehatan Gigi dan Mulut Guru Penjaskes SD di Kecamatan Rendang Tahun 2013. J Kesehat Gig. 2013;4(1): P. 3.

20. Mubarak WI, Chayatin N, Rozikin S. Promosi Kesehatan Sebuah Pengantar Proses Belajar Mengajar dalam Pendidikan. Yogyakarta Graha Ilmu. 2007;30.

21. Budiharto. Pengantar Ilmu Perilaku Kesehatan dan Pendidikan Kesehatan Gigi. Jakarta: EGC. Jakarta; 2010. P. 60-89

22. Syaer S. Faktor-faktor yang Berhubungan dengan Perilaku Mencari Pengobatan. Fakultas Kesehatan Masyarakat. Universitas Hasanuddin. 2010.

23. Irmawati I, Kurniasari R. Pengaruh Kualitas Pelayanan Jasa Terhadap Keputusan Pasien Berobat Rawat Inap di RSUD Moewardi Jebres. Benefit J Manaj dan Bisnis. 2012;15(1): P. 27-52.

24. Manu AA. Perilaku Pencarian Pengobatan Penyakit Gigi pada Masyarakat. Dent Ther J. 2019;1(1): P. 1-11.

25. Wawan A, Dewi M. Teori dan Pengukuran Pengetahuan, Sikap dan Perilaku Manusia. Yogyakarta Nuha Med. 2010; P. 11-18. 